\title{
Rate Coefficient and Product Branching Measurements for the Reaction OH + Bromopropane from 230 to $360 \mathrm{~K}$
}

\author{
Mary K. Gilles, ${ }^{\dagger}$ James B. Burkholder, Tomasz Gierczak, ${ }^{\dagger, *}$ Paul Marshall, ${ }^{\dagger, \S}$ and \\ A. R. Ravishankara $*, \neq$ \\ Aeronomy Laboratory, National Oceanic and Atmospheric Administration, 325 Broadway, \\ Boulder, Colorado 80305-3328
}

Received: December 31, 2001; In Final Form: March 25, 2002

\begin{abstract}
Rate coefficients over the range of $230-360 \mathrm{~K}$ were measured for the reaction of $\mathrm{OH}$ with the following bromopropane isotopomers: $\mathrm{CH}_{3} \mathrm{CH}_{2} \mathrm{CH}_{2} \mathrm{Br}\left(k_{1}\right), \mathrm{CD}_{3} \mathrm{CH}_{2} \mathrm{CH}_{2} \mathrm{Br}\left(k_{2}\right), \mathrm{CD}_{3} \mathrm{CH}_{2} \mathrm{CD}_{2} \mathrm{Br}\left(k_{3}\right), \mathrm{CH}_{3} \mathrm{CD}_{2} \mathrm{CD}_{2} \mathrm{Br}$ $\left(k_{4}\right)$, and $\mathrm{CD}_{3} \mathrm{CD}_{2} \mathrm{CD}_{2} \mathrm{Br}\left(k_{5}\right)$. The hydroxyl radical was produced by pulsed laser photolysis and detected via laser induced fluorescence. Reaction 1 can occur by $\mathrm{H}$ atom abstraction from three different carbon sites: $\mathrm{OH}+\mathrm{CH}_{3} \mathrm{CH}_{2} \mathrm{CH}_{2} \mathrm{Br} \rightarrow \mathrm{CH}_{3} \mathrm{CH}_{2} \mathrm{CHBr}+\mathrm{H}_{2} \mathrm{O}(1 \mathrm{a} ; \alpha) ; \rightarrow \mathrm{CH}_{3} \mathrm{CHCH}_{2} \mathrm{Br}+\mathrm{H}_{2} \mathrm{O}(1 \mathrm{~b} ; \beta) ;$ or $\rightarrow \mathrm{CH}_{2} \mathrm{CH}_{2-}$ $\mathrm{CH}_{2} \mathrm{Br}+\mathrm{H}_{2} \mathrm{O}(1 \mathrm{c} ; \gamma)$. Branching ratios obtained from an analysis of the kinetic data at $298 \mathrm{~K}$ are $k_{1 \mathrm{c}} / k_{1}=$ $0.12 \pm 0.08, k_{1 \mathrm{~b}} / k_{1}=0.56 \pm 0.04$, and $k_{1 \mathrm{a}} / k_{1}=0.32 \pm 0.08$; uncertainties given are 2 standard deviations and do not include systematic uncertainties. Stable products formed following reaction 1 in a $\mathrm{NO}_{x} / \mathrm{O}_{2}$ environment were measured using long path infrared absorption. Bromoacetone and propanal were observed in the ratio $\left[\left(\mathrm{CH}_{3} \mathrm{C}(\mathrm{O}) \mathrm{CH}_{2} \mathrm{Br}\right) /\left(\mathrm{CH}_{3} \mathrm{CH}_{2} \mathrm{CHO}\right)\right]$ of $1.65 \pm 0.50$ with an absolute bromoacetone yield of $0.5 \pm$ 0.2 at room temperature. The product yields are consistent with the rate coefficient data. Ab initio calculations show that $\mathrm{C}-\mathrm{H}$ bond energies at both the $\alpha$ and $\beta$ sites decrease (relative to propane) by the addition of $\mathrm{Br}$ at the $\alpha$ site. The calculated transition state energies decrease in the order $\gamma>\alpha>\beta$, in qualitative agreement with the experimental observations.
\end{abstract}

\section{Introduction}

Bromopropane, $\mathrm{CH}_{3} \mathrm{CH}_{2} \mathrm{CH}_{2} \mathrm{Br}$, has been proposed as a $\mathrm{CFC}$ substitute for application as an industrial solvent. Understanding the impact of this compound on the atmosphere requires knowledge of its atmospheric lifetime. Previous laboratory studies $^{1-5}$ show that reaction with $\mathrm{OH}$ is the primary loss process for $\mathrm{CH}_{3} \mathrm{CH}_{2} \mathrm{CH}_{2} \mathrm{Br}$ and its atmospheric lifetime is $\sim 10$ days. ${ }^{4-8}$ Recent model studies ${ }^{6,7}$ have shown that the ODP of bromopropane depends on the season, location of the emissions, atmospheric transport, and the lifetimes of the tropospheric end products of the $\mathrm{OH}+$ bromopropane reaction. Hence, the atmospheric impact of this short-lived compound on stratospheric ozone also depends on the products of the $\mathrm{OH}+$ bromopropane reaction.

The $\mathrm{H}$ atom abstraction by $\mathrm{OH}$ in the reaction

$$
\begin{aligned}
\mathrm{OH}+\mathrm{CH}_{3} \mathrm{CH}_{2} \mathrm{CH}_{2} \mathrm{Br} & \rightarrow \mathrm{CH}_{3} \mathrm{CH}_{2} \mathrm{CHBr}+\mathrm{H}_{2} \mathrm{O} \\
& \rightarrow \mathrm{CH}_{3} \mathrm{CHCH}_{2} \mathrm{Br}+\mathrm{H}_{2} \mathrm{O} \\
& \rightarrow \mathrm{CH}_{2} \mathrm{CH}_{2} \mathrm{CH}_{2} \mathrm{Br}+\mathrm{H}_{2} \mathrm{O}
\end{aligned}
$$

occurs from different sites along the carbon chain. In this work,

* To whom correspondence should be addressed. NOAA R/AL2, 325 Broadway, Boulder, CO 80305. E-mail: ravi@al.noaa.gov.

$\dagger$ Affiliated with the Cooperative Institute for Research in Environmental Sciences, University of Colorado, Boulder, CO 80309.

$\doteqdot$ Department of Chemistry, Warszawa University, 02-089 Warszawa, ul. Zwirki I Wigury 101, Warszawa, Poland.

$\S$ Department of Chemistry, University of North Texas, P.O. Box 305070 , Denton, TX 76203.

"Also affiliated with the Department of Chemistry and Biochemistry, University of Colorado, Boulder, CO 80309. we use $\alpha, \beta$, and $\gamma\left({ }^{\gamma} \mathrm{CH}_{3}{ }^{\beta} \mathrm{CH}_{2}{ }^{\alpha} \mathrm{CH}_{2} \mathrm{Br}\right)$ to denote reaction at various carbon sites. Abstraction from each carbon site results in distinct tropospheric degradation products, which may impact the extent of stratospheric ozone loss differently. Therefore, product branching ratios from the $\mathrm{OH}+$ bromopropane reaction are needed. To date, products have not been identified and branching ratios have not been measured. In the absence of experimental data, modeling studies ${ }^{7,8}$ have assumed hydrogen abstraction from various sites using the empirical structurereactivity relationships of Atkinson. ${ }^{9,10}$

In this paper, we report the rate coefficients, $k_{1}(\mathrm{~T})-k_{5}(\mathrm{~T})$, for the reaction of various isotopomers of bromopropane with $\mathrm{OH}$ :

$$
\begin{aligned}
& \mathrm{OH}+\mathrm{CH}_{3} \mathrm{CH}_{2} \mathrm{CH}_{2} \mathrm{Br} \rightarrow \text { products; } k_{1} \\
& \mathrm{OH}+\mathrm{CD}_{3} \mathrm{CH}_{2} \mathrm{CH}_{2} \mathrm{Br} \rightarrow \text { products; } k_{2} \\
& \mathrm{OH}+\mathrm{CD}_{3} \mathrm{CH}_{2} \mathrm{CD}_{2} \mathrm{Br} \rightarrow \text { products; } k_{3} \\
& \mathrm{OH}+\mathrm{CH}_{3} \mathrm{CD}_{2} \mathrm{CD}_{2} \mathrm{Br} \rightarrow \text { products; } k_{4} \\
& \mathrm{OH}+\mathrm{CD}_{3} \mathrm{CD}_{2} \mathrm{CD}_{2} \mathrm{Br} \rightarrow \text { products; } k_{5}
\end{aligned}
$$

These rate coefficients are used to obtain branching ratios for site specific $\mathrm{H}$ atom abstraction as a function of temperature using an analysis similar to that used by Droege and Tully for the $\mathrm{OH}+$ propane reaction. ${ }^{11} \mathrm{We}$ also report the yield of stable products formed following the reaction of bromopropane with $\mathrm{OH}$ and $\mathrm{Cl}$. Finally, we discuss the measured yields in light of 
the calculated $\mathrm{C}-\mathrm{H}$ bond energies and the transition states for reaction at each carbon site.

\section{Experimental Section}

The $\mathrm{OH}$ rate coefficient measurements and end product analysis are described separately in the following sections.

Rate Coefficient Measurements. The rate coefficients $k_{1}$ $(\mathrm{T})-k_{5}(\mathrm{~T})$ were measured as a function of temperature using a pulsed laser photolysis-laser induced fluorescence (PP-LIF) system and procedures are described in detail elsewhere. ${ }^{12}$ Gas mixtures containing the $\mathrm{OH}$ precursor, buffer gas (50 Torr of $\mathrm{He}$ ), and bromopropane flowed slowly through the cell. $\mathrm{OH}$ radicals were produced by $351 \mathrm{~nm}$ pulsed laser photolysis of HONO. All experiments were carried out under pseudo-firstorder conditions in $\mathrm{OH}$, ([bromopropane $] /[\mathrm{OH}]_{0}>1500$ ), where $[\mathrm{OH}]_{0}$ is the initial $\mathrm{OH}$ radical concentration. The $\mathrm{OH}$ temporal profiles followed a simple exponential rate law:

$$
[\mathrm{OH}]_{t}=[\mathrm{OH}]_{0} \exp \left(-k_{i}^{\prime} t\right)
$$

where $k_{i}^{\prime}=k_{i}[\mathrm{X}]+k_{\mathrm{d}}, k_{\mathrm{d}}$ is the first-order rate coefficient for the loss of $\mathrm{OH}$ in the absence of bromopropane, $[\mathrm{X}]$ is the bromopropane concentration, and the subscript $i$ runs from 1 to 5. The loss of $\mathrm{OH}$ in the absence of bromopropane is attributed to reaction with the photolytic precursor (and its impurities, e.g., $\mathrm{NO}_{2}$ ), diffusion out of the detection zone, and reaction with impurities in the bath gas. Values of $k_{i}^{\prime}$ were measured at various bromopropane concentrations, and $k_{i}$ was obtained from the slope of a plot of $k_{i}^{\prime}$ vs $[\mathrm{X}]$.

The HONO concentration was estimated from $k_{\mathrm{d}}$, the firstorder rate coefficient in the absence of bromopropane, and attributed to the reaction ${ }^{13}$

$$
\begin{gathered}
\mathrm{OH}+\mathrm{HONO} \rightarrow \mathrm{H}_{2} \mathrm{O}+\mathrm{NO}_{2} \\
k_{6}(\mathrm{~T})=\left(1.8 \times 10^{-11}\right) \exp (-390 / T) \mathrm{cm}^{3} \text { molecule } \mathrm{s}^{-1} \mathrm{~s}^{-1}
\end{gathered}
$$

Values of $k_{\mathrm{d}}$ ranged from 100 to $200 \mathrm{~s}^{-1}$. These values place an upper limit to the HONO concentration of $(2.8-7.6) \times 10^{13}$ molecule $\mathrm{cm}^{-3}$. The intercept from the fits of $k_{i}^{\prime}$ versus [X] were within $10 \%$ of the value measured for $k_{\mathrm{d}}$ in the absence of bromopropane. Upper limits for $[\mathrm{OH}]_{0}$ ranged from $1 \times 10^{11}$ to $5 \times 10^{11}$ molecule $\mathrm{cm}^{-3}$ and were calculated from the HONO concentration, the measured photolysis laser fluence, the HONO absorption cross section at $351 \mathrm{~nm}\left(2.12 \times 10^{-19} \mathrm{~cm}^{2}\right.$ molecule $\left.{ }^{-1}\right)$, and a quantum yield of 1 for $\mathrm{OH}$ production. ${ }^{13}$

The bromopropane concentration in the gas flowing through the reactor was measured by absorption at $214 \mathrm{~nm}$ (Zn pen-ray lamp) at room temperature $(298 \pm 2 \mathrm{~K})$ in $50 \mathrm{~cm}$ cells located before and after the reaction cell. The measured concentrations in the two cells agreed within $\pm 3 \%$ over the range of concentrations, temperatures and pressures used in the kinetic measurements. The average of the two values was used in the kinetic analysis after correcting for the temperature difference between the room-temperature absorption cells and the reactor. The reactor was heated or cooled by circulating a fluid from a thermostated bath through its jacket.

The absorption cross section of $\mathrm{CH}_{3} \mathrm{CH}_{2} \mathrm{CH}_{2} \mathrm{Br}$ at 214 was determined previously in our laboratory. ${ }^{2}$ In this work, the absorption cross sections of $\mathrm{CH}_{3} \mathrm{CH}_{2} \mathrm{CH}_{2} \mathrm{Br}$ and two isotopomers were measured using a similar method. The absorption cross sections obtained were $\mathrm{CD}_{3} \mathrm{CD}_{2} \mathrm{CD}_{2} \mathrm{Br}\left[(4.71 \pm 0.10) \times 10^{-19}\right.$ $\mathrm{cm}^{2}$ molecule ${ }^{-1}$ ], $\mathrm{CD}_{3} \mathrm{CH}_{2} \mathrm{CH}_{2} \mathrm{Br}\left[(4.97 \pm 0.08) \times 10^{-19} \mathrm{~cm}^{2}\right.$ molecule $\left.{ }^{-1}\right]$, and $\mathrm{CH}_{3} \mathrm{CH}_{2} \mathrm{CH}_{2} \mathrm{Br}\left[(4.93 \pm 0.09) \times 10^{-19} \mathrm{~cm}^{2}\right.$ molecule $\left.{ }^{-1}\right]$. This uncertainty is $2 \sigma$ from the precision of the fit to the data and does not include uncertainties in pressure or the path length. The isotopomer absorption cross sections fell within $5 \%$ of one another and of the previously measured value. ${ }^{2}$ To be consistent with the previous work from this laboratory, we have used $4.85 \times 10^{-19} \mathrm{~cm}^{2}$ molecule $\mathrm{e}^{-1}$ as the absorption cross section at $214 \mathrm{~nm}$ for all of the bromopropane isotopomers.

Photolytic production of $\mathrm{OH}$ at $351 \mathrm{~nm}$ was advantageous because bromopropane photolysis was minimized (compared to $248 \mathrm{~nm}$ photolysis). The photolysis laser fluence was varied over the range $(7-19) \mathrm{mJ}$ pulse $\mathrm{e}^{-1} \mathrm{~cm}^{-2}$. The $\mathrm{OH}$ probe laser fluence ranged from 0.2 to $0.4 \mathrm{~mJ}$ pulse $\mathrm{cm}^{-1}$. Kinetics experiments were performed with total gas flow rates of 215$250 \mathrm{sccm}$, at pressures of $\sim 50$ Torr of He, resulting in linear gas flow velocities from 9 to $16 \mathrm{~cm} \mathrm{~s}^{-1}$.

Product Formation. Possible products generated in the atmospheric degradation of bromopropane after reaction with $\mathrm{OH}$ are

$$
\begin{gathered}
\mathrm{CH}_{3} \mathrm{CH}_{2} \mathrm{C}(\mathrm{O}) \mathrm{H}+\mathrm{Br}(\mathrm{H} \text { abstraction reaction } 1 \mathrm{a}) \\
\mathrm{CH}_{3} \mathrm{C}(\mathrm{O}) \mathrm{CH}_{2} \mathrm{Br}+\mathrm{HO}_{2}(\mathrm{H} \text { abstraction reaction } 1 \mathrm{~b}) \\
\mathrm{CH}(\mathrm{O}) \mathrm{CH}_{2} \mathrm{CH}_{2} \mathrm{Br}+\mathrm{HO}_{2}(\mathrm{H} \text { abstraction reaction } 1 \mathrm{c})
\end{gathered}
$$

These products are generated through the $\mathrm{RO}_{2}$ radicals produced from the alkyl radical, $\mathrm{R} \bullet$. The detailed mechanism for formation of these products is discussed elsewhere. . $^{814,15}$

Because unique products are formed for each site where $\mathrm{H}$ atom abstraction occurs, measurement of the above products provides information on the branching ratios in reaction 1 . Therefore, we have measured the degradation products formed following reaction 1 in 620 Torr of synthetic air containing $\mathrm{NO}_{x}$ $\left(\mathrm{NO}_{x}=\mathrm{NO}+\mathrm{NO}_{2}\right)$ as a part of this work. Degradation products from the $\mathrm{Cl}$ atom initiated oxidation of bromopropane were also measured under similar experimental conditions.

The experimental apparatus ${ }^{16}$ for the reaction product studies consisted of an $18 \mathrm{~L}$ cylindrical glass photolysis/reaction cell equipped with multipass infrared White optics that coupled to a Fourier transform infrared spectrometer. The cell was surrounded by three light banks, each consisting of eight fluorescent lamps emitting UV radiation (300-400 nm with the peak intensity near $350 \mathrm{~nm}) .{ }^{17}$ The infrared optical path length was $29.5 \mathrm{~m}$. Absorption spectra were measured over the range of $800-4000 \mathrm{~cm}^{-1}$ at $1 \mathrm{~cm}^{-1}$ resolution.

$\mathrm{OH}$ radicals were produced following the photolysis of $\mathrm{CH}_{3}-$ $\mathrm{ONO}$ in the presence of $\mathrm{NO}$ and $\mathrm{O}_{2}$

$$
\begin{gathered}
\mathrm{CH}_{3} \mathrm{ONO}+h v \rightarrow \mathrm{CH}_{3} \mathrm{O}+\mathrm{NO} \\
\mathrm{CH}_{3} \mathrm{O}+\mathrm{O}_{2} \rightarrow \mathrm{CH}_{2} \mathrm{O}+\mathrm{HO}_{2} \\
\mathrm{HO}_{2}+\mathrm{NO} \rightarrow \mathrm{OH}+\mathrm{NO}_{2}
\end{gathered}
$$

In the $\mathrm{Cl}$ atom initiated oxidation experiments, $\mathrm{Cl}$ atoms were produced by the photolysis of $\mathrm{Cl}_{2}$. To obtain product yields, infrared absorption spectra of the reaction mixture were measured prior to photolysis and after 2-5 min of photolysis, for total photolysis times between 5 and $20 \mathrm{~min}$. Photolysis of bromopropane by the UV lamps was measured to be negligible. The initial concentrations used in these experiments were $0.05-$ 0.5 Torr of bromopropane, 0.1 Torr of $\mathrm{CH}_{3} \mathrm{ONO}, 0.01$ Torr of $\mathrm{NO}$, and $0.05-0.12$ Torr of $\mathrm{Cl}_{2}$.

Materials. Isotopically substituted bromopropane compounds were obtained commercially \{bromopropane-3,3,3-D3; bro- 
mopropane-1,1,2,2-D4; bromopropane-1,1,3,3,3-D5; and bromopropane-D7\}. The stated isotopic purity was $>98 \%$ (except $\mathrm{CD}_{3} \mathrm{CH}_{2} \mathrm{CH}_{2} \mathrm{Br}$ which was $>99 \%$ ), and no chemical purity was stated. The $\mathrm{CH}_{3} \mathrm{CH}_{2} \mathrm{CH}_{2} \mathrm{Br}$ sample (99\% purity) was used in the previous study from this laboratory. ${ }^{2}$ All samples were degassed under vacuum with numerous freeze-thaw cycles and were stored in Pyrex containers that were stored in a refrigerator when not in use. The sample was introduced into the gas flow from the reservoir through a stainless steel double-needle valve while the liquid sample was maintained at $25^{\circ} \mathrm{C}$.

The impurities in bromopropane and its deuterated analogues were identified using gas chromatography-mass spectrometry (GC/MS). After identification, impurities were quantified using a flame ionization detector (FID). A nonpolar column (SPB-5, $30 \mathrm{~m}, 0.32 \mathrm{~mm}, 0.5 \mu \mathrm{m}$ film) was used with a temperature control program. For quantification, standards of $n$-hexane (3.3 $\mathrm{mg} / \mathrm{mL})$, bromopropane $(6.77 \mathrm{mg} / \mathrm{mL}), 2$-pentanone $(405 \mathrm{mg} /$ $\mathrm{mL})$, and 2,3-dibromopropane $(10.15 \mathrm{mg} / \mathrm{mL})$ were prepared in methanol. All compounds containing a single bromine atom (ethyl bromide, propyl bromides, butyl bromides, and bromohexanes) were assumed to have the same response in the FID as bromopropane. Similarly, 2,3-dibromopropane was a proxy for dibromo compounds; $n$-hexane for $n$-pentane, $n$-hexanes, sulfides, disulfides, and siloxanes; 1-chlorohexane for propyl chloride; and 2-pentanone for acetone, tert-butyl methyl ketone, and 3-methyl-2-butanone. Details of the gas chromatography/ mass spectrometry analyses for each compound and an estimate of their contribution to the measured reaction rate coefficients at $230 \mathrm{~K}$ are given in Tables S1a-S1e of the Supporting Information. Total impurity contributions at $230 \mathrm{~K}$ calculated from Tables S1a-S1e were $<4 \%$ for $k_{1},<7 \%$ for $k_{2},<4 \%$ for $k_{3},<5 \%$ for $k_{4}$, and $<7 \%$ for $k_{5}$.

A general concern in the measurements of $k_{1}$ was the possibility of $\mathrm{Br}_{2}$ contamination. The rate coefficient for the reaction of $\mathrm{OH}$ with $\mathrm{Br}_{2}$

$$
\mathrm{OH}+\mathrm{Br}_{2} \rightarrow \mathrm{HOBr}+\mathrm{Br}
$$

is large and increases with decreasing temperature. ${ }^{18,19}$ Therefore, the contribution of reaction 10 would be more pronounced at lower temperatures. For example, a $0.5 \% \mathrm{Br}_{2}$ contamination in bromopropane would account for $40 \%$ of the measured value of $k_{1}$ at $230 \mathrm{~K}$ and $15 \%$ at $360 \mathrm{~K}$. One should note that $\mathrm{Br}_{2}$ impurity levels of $3 \%$ in $\mathrm{CH}_{3} \mathrm{CH}_{2} \mathrm{CH}_{2} \mathrm{Br}$ or $\mathrm{CD}_{3} \mathrm{CH}_{2} \mathrm{CH}_{2} \mathrm{Br}, 2 \%$ in $\mathrm{CD}_{3} \mathrm{CH}_{2} \mathrm{CD}_{2} \mathrm{Br}$, and $1 \%$ in $\mathrm{CH}_{3} \mathrm{CD}_{2} \mathrm{CD}_{2} \mathrm{Br}$ or $\mathrm{CD}_{3} \mathrm{CD}_{2} \mathrm{CD}_{2^{-}}$ $\mathrm{Br}$ would lead to measured values of $k_{1}-k_{5}$ that were temperature independent. Therefore, we determined an upper limit of the $\mathrm{Br}_{2}$ impurity by UV/vis absorption using a diode array spectrometer with a $\mathrm{D}_{2}$ lamp. A $65 \mathrm{~cm}$ long single pass absorption cell was filled with 20-85 Torr of bromopropane. The absorbance for each isotopomer was measured between 277 and $510 \mathrm{~nm}$. $\mathrm{Br}_{2}$ absorbs from 320 to $600 \mathrm{~nm}$ with a peak absorption cross section of $6 \times 10^{-19} \mathrm{~cm}^{2}$ molecule ${ }^{-1}$ at 400 $\mathrm{nm} .{ }^{20}$ No absorption could be attributed to $\mathrm{Br}_{2}$ in any of the isotopomers. The $\mathrm{Br}_{2}$ contamination was estimated to be $<60$ ppmv for all samples. $\mathrm{HBr}$, a potentially reactive impurity, was not measured. We assume that $\mathrm{HBr}$, given its large vapor pressure, would have been pumped off prior to the rate coefficient measurements.

HONO was made from the dropwise addition of a $0.1 \mathrm{M}$ solution of $\mathrm{NaNO}_{2}$ to a $10 \%$ sulfuric acid solution in a flask which was kept in an ice bath. The small flow of He through the flask was varied to control the HONO concentration entering the reaction cell. These mixtures were replaced daily.
TABLE 1: Experimental Parameters in Measurements of $k_{1}(\mathrm{~T})^{a}$

\begin{tabular}{ccccc}
\hline$K$ & {$[\mathrm{HONO}]$} & {$[\mathrm{OH}]_{0}$} & {$\left[\mathrm{CH}_{3} \mathrm{CH}_{2} \mathrm{CH}_{2} \mathrm{Br}\right]$} & $k_{1}$ \\
\hline 230 & 6.1 & 3.3 & $5.30-20.2$ & $6.52 \pm 0.38$ \\
233 & 3.8 & 2.4 & $2.31-23.8$ & $7.57 \pm 0.20$ \\
244 & 6.0 & 3.7 & $4.99-14.9$ & $7.22 \pm 0.18$ \\
262 & 7.6 & 4.1 & $2.98-19.0$ & $8.29 \pm 0.18$ \\
281 & 3.7 & 2.2 & $4.82-12.7$ & $8.86 \pm 0.25$ \\
$297^{b}$ & 2.9 & 1.8 & $2.76-27.9$ & $9.72 \pm 0.32$ \\
299 & 3.8 & 2.0 & $3.14-14.3$ & $9.35 \pm 0.34$ \\
315 & 6.3 & 2.8 & $1.32-7.21$ & $11.0 \pm 0.46$ \\
330 & 3.8 & 1.3 & $0.83-7.56$ & $11.1 \pm 0.71$ \\
345 & 3.1 & 1.4 & $1.05-6.21$ & $12.3 \pm 0.64$ \\
360 & 2.8 & 1.2 & $0.94-5.47$ & $13.4 \pm 0.19$
\end{tabular}

${ }^{a}$ Concentrations are in units of $10^{13}$ for HONO, $10^{11}$ for $\mathrm{OH}$, and $10^{15}$ for $\mathrm{CH}_{3} \mathrm{CH}_{2} \mathrm{CH}_{2} \mathrm{Br}$ all in molecule $\mathrm{cm}^{-3}, k_{1}$ is in units of $10^{-13}$ $\mathrm{cm}^{3}$ molecule ${ }^{-1} \mathrm{~s}^{-1}$, and the uncertainty given for $k_{1}$ is $2 \sigma$ precision from the fit to the data and does not include systematic uncertainties. ${ }^{b}$ Probe laser fluence was decreased by a factor of 2 to $0.2 \mathrm{~mJ}$ pulse ${ }^{-1}$ $\mathrm{cm}^{-2}$.

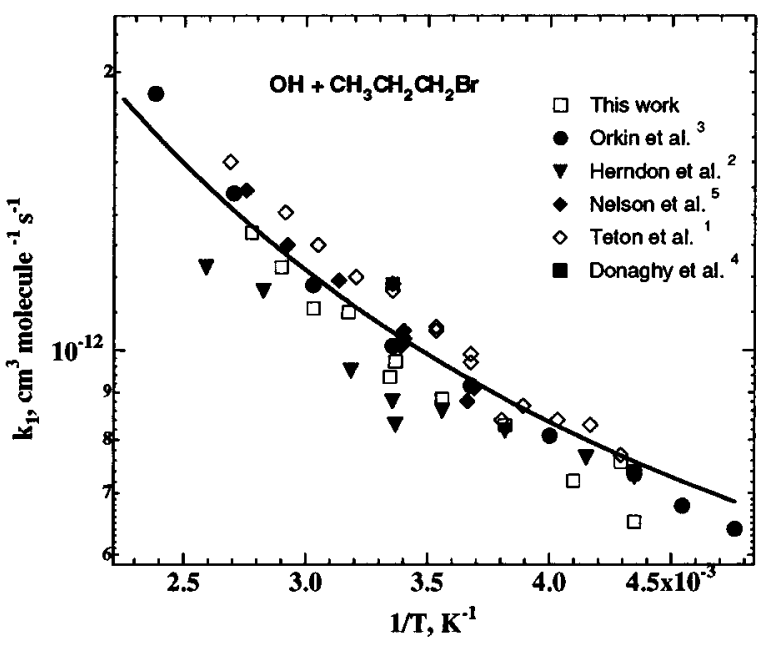

Figure 1. Rate coefficients measured for the reaction of $\mathrm{OH}$ with $\mathrm{CH}_{3}-$ $\mathrm{CH}_{2} \mathrm{CH}_{2} \mathrm{Br}$ in this work and in previous work. The fit recommended for modeling is shown by the solid line.

\section{Results and Discussion}

Measurements of $\boldsymbol{k}_{1}(\mathrm{~T}), \mathrm{OH}+\mathrm{CH}_{3} \mathrm{CH}_{2} \mathrm{CH}_{2} \mathrm{Br}$. We remeasured $k_{1}(\mathrm{~T})$ using the same apparatus and identical experimental conditions as those used for determining $k_{2}(\mathrm{~T})-k_{5}(\mathrm{~T})$. These measurements were performed to reduce the uncertainties in $k_{2}(\mathrm{~T})-k_{5}(\mathrm{~T})$ relative to $k_{1}(\mathrm{~T})$ by cancellation of systematic errors. Our measured values given in Table 1 agree with previously reported values. $k_{1}(\mathrm{~T})$ increases with increasing temperature, and an Arrhenius plot of the data displays slight curvature. Previous studies have chosen to fit the curvature with a variety of functional forms, but we fit our data to the form $k_{1}(\mathrm{~T})=A T^{2} \exp (-B / T)$. Previous results, those from this study, and the recent data of Orkin et al. ${ }^{3}$ are summarized in Table 2 and presented in Figure 1. All reported measurements of $k_{1}$ are within $8 \%$ of one another around $250 \mathrm{~K}$, with the disagreement increasing to $\sim 30 \%$ at temperatures closer to $400 \mathrm{~K}$. Although the disagreement is largest at higher temperatures, for atmospheric purposes, this is the least relevant temperature range. Our current values agree within $5 \%$ at $298 \mathrm{~K}$ with our previously reported value. ${ }^{2}$ However, the $360 \mathrm{~K}$ value measured here is $15 \%$ larger than that reported by Herndon et al. ${ }^{2}$ The fit to all of the published data yields $k_{1}(\mathrm{~T})=(6.08 \pm 1.57) \times 10^{-18} T^{2}$ $\exp [-(-197 \pm 77) / T] \mathrm{cm}^{3}$ molecule $\mathrm{s}^{-1} \mathrm{~s}^{-1}$, which we recommend for use by atmospheric modelers. 
TABLE 2: Comparison with the Previous Measurements of $\mathrm{OH}+\mathrm{CH}_{3} \mathrm{CH}_{2} \mathrm{CH}_{2} \mathrm{Br}, k_{1}(\mathrm{~T})=A T^{\mathrm{n}} \mathrm{e}^{-B / T}$

\begin{tabular}{|c|c|c|c|c|c|c|c|}
\hline $\begin{array}{c}A, \\
\mathrm{~cm}^{3} \text { molecule }^{-1} \mathrm{~s}^{-1}\end{array}$ & $n$ & $B, \mathrm{~K}$ & temp, $\mathrm{K}$ & $\begin{array}{l}\text { pressure, }{ }^{a} \\
\text { Torr }\end{array}$ & $\begin{array}{c}k_{1}(298 \mathrm{~K}) 10^{-13} \\
\mathrm{~cm}^{3} \text { molecule }{ }^{-1} \mathrm{~s}^{-1}\end{array}$ & technique $^{b}$ & ref \\
\hline$(6.6 \pm 0.52) \times 10^{-18}$ & 2 & $-(154 \pm 24)$ & $230-360$ & 50 & $9.53 \pm 0.37$ & PP-LIF & This work ${ }^{c}$ \\
\hline$d$ & & & $210-480$ & & $10.10 \pm 0.15$ & $\mathrm{FP}-\mathrm{RF}$ & Orkin et al. ${ }^{3}$ \\
\hline $9.1 \times 10^{-14}$ & 0.5 & $(157 \pm 62)$ & $230-298$ & 100 & $8.7 \pm 0.4$ & PP-LIF & Herndon et al. ${ }^{2}$ \\
\hline$(5.75 \pm 0.9) \times 10^{-12}$ & 0 & $(504 \pm 50)$ & $271-363$ & $1.1-2.3$ & $10.3 \pm 1.5$ & DF-LIF & Nelson et al. ${ }^{5}$ \\
\hline$(5.29 \pm 0.29) \times 10^{-12}$ & 0 & $(456 \pm 31)$ & $233-372$ & 100 & $11.7 \pm 1.2$ & PP-LIF & Téton et al. ${ }^{1}$ \\
\hline$(6.08 \pm 1.57) \times 10^{-18}$ & 2 & $-(197 \pm 77)$ & $\begin{array}{l}298 \\
230-372\end{array}$ & & $11.8 \pm 3.0$ & $\mathrm{RR}$ & $\begin{array}{l}\text { Donaghy et al. }{ }^{4} \\
\text { Recommended for Modeling }\end{array}$ \\
\hline
\end{tabular}

${ }^{a}$ Experiments were done in He buffer gas. ${ }^{b} \mathrm{PP}-\mathrm{LIF}$ is pulsed laser photolysis followed by laser induced fluorescence detection of OH, FP-RF is flash photolysis followed by resonance fluorescence detection, DF-LIF is discharge flow followed by laser induced fluorescence detection of OH, and $\mathrm{RR}$ is relative to the reaction rate of $\mathrm{OH}$ with $\left(c-\mathrm{C}_{6} \mathrm{H}_{12}\right) .{ }^{c}$ The $298 \mathrm{~K}$ value is obtained by converting the measured values near $298 \mathrm{~K}$ using the value of $B$ determined from the fit to the data. ${ }^{d}$ These authors represented their data $k_{1}(T<298 \mathrm{~K})=(1.01 \pm 0.02) \times 10^{-12} \exp \{-(329 \pm$ $20)(1 / T-1 / 298 \mathrm{~K})\}$. This recommendation does not include the work of Orkin et al. ${ }^{3}$ If the unpublished data of Orkin et al. is included, the resulting expression is: $k_{1}(\mathrm{~T})=(7.40 \pm 1.07) \times 10^{-18} T^{2} \exp [-(-140 \pm 45) / T]$.

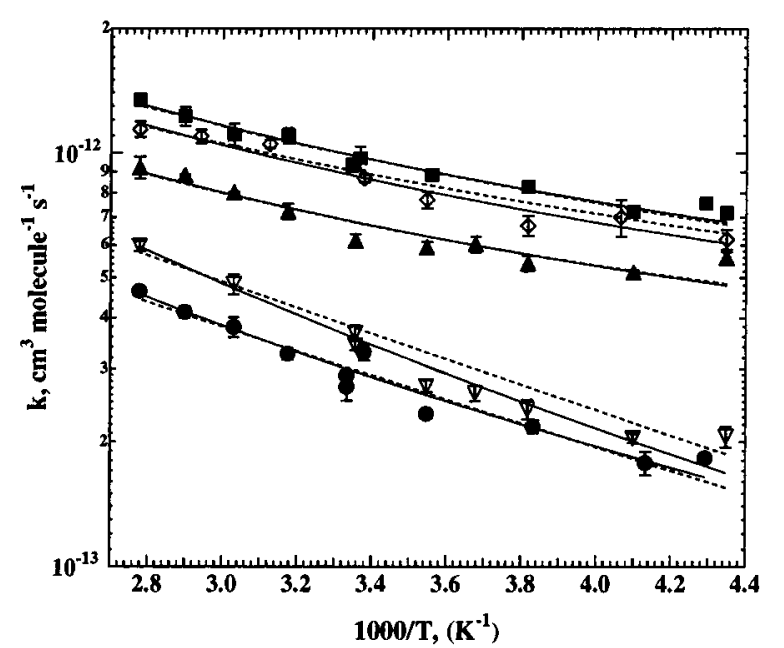

Figure 2. Rate coefficients measured for the reaction of $\mathrm{OH}$ with bromopropane isotopomers: $\mathrm{CH}_{3} \mathrm{CH}_{2} \mathrm{CH}_{2} \mathrm{Br}(\mathbf{\square}), \mathrm{CD}_{3} \mathrm{CH}_{2} \mathrm{CH}_{2} \mathrm{Br}(\diamond)$, $\mathrm{CD}_{3} \mathrm{CH}_{2} \mathrm{CD}_{2} \mathrm{Br}(\boldsymbol{\Delta}), \mathrm{CH}_{3} \mathrm{CD}_{2} \mathrm{CD}_{2} \mathrm{Br}(\nabla), \mathrm{CD}_{3} \mathrm{CD}_{2} \mathrm{CD}_{2} \mathrm{Br}(\bullet)$. The solid lines represent the fits of the data to the expression $A T^{2} \exp (-B / R T)$ and are given in Table 7 . The dashed lines are fit using the site dependent rate coefficients given in Table 8.

TABLE 3: Experimental Parameters Used for the Measurements of $k_{2}(T)^{a}$

\begin{tabular}{ccccc}
\hline$K$ & {$[\mathrm{HONO}]$} & {$[\mathrm{OH}]_{0}$} & {$\left[\mathrm{CD}_{3} \mathrm{CH}_{2} \mathrm{CH}_{2} \mathrm{Br}\right]$} & $k_{2}$ \\
\hline 230 & 6.4 & 3.4 & $1.87-9.82$ & $6.19 \pm 0.32$ \\
246 & 8.9 & 2.0 & $0.95-8.77$ & $7.01 \pm 0.71$ \\
262 & 3.2 & 1.7 & $1.94-9.46$ & $6.68 \pm 0.36$ \\
282 & 3.2 & 1.7 & $1.17-7.87$ & $7.72 \pm 0.36$ \\
296 & 2.8 & 1.9 & $6.14-15.3$ & $8.68 \pm 0.18$ \\
320 & 4.5 & 2.4 & $1.01-5.65$ & $10.5 \pm 0.3$ \\
340 & 3.9 & 0.9 & $1.20-5.65$ & $11.0 \pm 0.4$ \\
360 & 2.7 & 1.5 & $0.67-5.47$ & $11.4 \pm 0.5$
\end{tabular}

${ }^{a}$ Concentrations are in units of $10^{13}$ for HONO, $10^{11}$ for $\mathrm{OH}$, and $10^{15}$ for $\mathrm{CD}_{3} \mathrm{CH}_{2} \mathrm{CH}_{2} \mathrm{Br}$ all in molecule $\mathrm{cm}^{-3}, k_{2}$ is in units of $10^{-13}$ $\mathrm{cm}^{3}$ molecule ${ }^{-1} \mathrm{~s}^{-1}$, and the uncertainty given for $k_{2}$ is $2 \sigma$ precision from the fit to the data and does not include systematic uncertainties.

Measurements of $\mathrm{OH}+$ Bromopropane Isotopomers, $\boldsymbol{k}_{2}$ (T) $-\boldsymbol{k}_{\mathbf{5}}(\mathbf{T})$. Room-temperature rate coefficients for the reaction of $\mathrm{OH}$ with bromopropanes decrease in the order $\mathrm{CH}_{3} \mathrm{CH}_{2} \mathrm{CH}_{2}$ $\mathrm{Br}\left(k_{1}\right)>\mathrm{CD}_{3} \mathrm{CH}_{2} \mathrm{CH}_{2} \mathrm{Br}\left(k_{2}\right)>\mathrm{CD}_{3} \mathrm{CH}_{2} \mathrm{CD}_{2} \mathrm{Br}\left(k_{3}\right)>\mathrm{CH}_{3}-$ $\mathrm{CD}_{2} \mathrm{CD}_{2} \mathrm{Br}\left(k_{4}\right)>\mathrm{CD}_{3} \mathrm{CD}_{2} \mathrm{CD}_{2} \mathrm{Br}\left(k_{5}\right)$. Figure 2 displays a plot of $k_{i}$ vs $1000 / T$ for the five reactions studied here. The values of $k_{2}(\mathrm{~T})-k_{5}(\mathrm{~T})$ measured between 230 and $360 \mathrm{~K}$ and experimental parameters are given in Tables $3-6$. The rate coefficients all show a temperature dependence similar to that observed for $k_{1}$ (i.e., the rate coefficient increases with increasing tempera-
TABLE 4: Experimental Parameters Used for the Measurements of $k_{3}(T)^{a}$

\begin{tabular}{ccccc}
\hline$K$ & {$[\mathrm{HONO}]$} & {$[\mathrm{OH}]_{0}$} & {$\left[\mathrm{CD}_{3} \mathrm{CH}_{2} \mathrm{CD}_{2} \mathrm{Br}\right]$} & $k_{3}$ \\
\hline 230 & 6.4 & 3.4 & $0.97-12.9$ & $5.60 \pm 0.18$ \\
244 & 4.0 & 2.2 & $1.80-9.56$ & $5.16 \pm 0.06$ \\
262 & 3.6 & 2.0 & $1.23-9.39$ & $5.44 \pm 0.23$ \\
272 & 5 & 2.5 & $1.54-10.2$ & $6.03 \pm 0.26$ \\
282 & 3.5 & 1.9 & $1.20-9.86$ & $5.92 \pm 0.18$ \\
298 & 3.0 & 1.6 & $1.32-10.8$ & $6.15 \pm 0.21$ \\
315 & 4.3 & 2.4 & $0.45-6.23$ & $7.22 \pm 0.36$ \\
330 & 3.4 & 1.8 & $0.74-6.34$ & $8.04 \pm 0.12$ \\
345 & 2.6 & 1.4 & $1.06-4.73$ & $8.84 \pm 0.26$ \\
360 & 3.0 & 1.5 & $0.51-7.51$ & $9.22 \pm 0.56$
\end{tabular}

${ }^{a}$ Concentrations are in units of $10^{13}$ for $\mathrm{HONO}, 10^{11}$ for $\mathrm{OH}$, and $10^{15}$ for $\mathrm{CD}_{3} \mathrm{CH}_{2} \mathrm{CD}_{2} \mathrm{Br}$ all in molecule $\mathrm{cm}^{-3}, k_{3}$ is in units of $10^{-13}$ $\mathrm{cm}^{3}$ molecule ${ }^{-1} \mathrm{~s}^{-1}$, and the uncertainty given for $k_{3}$ is $2 \sigma$ precision from the fit to the data and does not include systematic uncertainties.

TABLE 5: Experimental Parameters Used for the Measurements of $k_{4}(\mathrm{~T})^{a}$

\begin{tabular}{ccccc}
\hline$K$ & {$[\mathrm{HONO}]$} & {$[\mathrm{OH}]_{0}$} & {$\left[\mathrm{CH}_{3} \mathrm{CD}_{2} \mathrm{CD}_{2} \mathrm{Br}\right]$} & $k_{4}$ \\
\hline 230 & 6.4 & 3.4 & $2.52-21.6$ & $2.06 \pm 0.12$ \\
244 & 5.3 & 2.8 & $3.10-19.7$ & $2.04 \pm 0.06$ \\
262 & 4.7 & 2.5 & $2.50-16.8$ & $2.40 \pm 0.13$ \\
727 & 16 & 7.9 & $4.30-14.1$ & $2.72 \pm 0.10$ \\
282 & 4.1 & 2.2 & $1.69-18.1$ & $2.62 \pm 0.12$ \\
298 & 2.7 & 1.4 & $2.89-15.0$ & $3.43 \pm 0.10$ \\
298 & 6.3 & 3.4 & $1.21-14.6$ & $3.68 \pm 0.16$ \\
330 & 7.0 & 3.3 & $2.42-10.6$ & $4.83 \pm 0.26$ \\
360 & 5.3 & 2.5 & $0.49-10.2$ & $5.97 \pm 0.16$
\end{tabular}

${ }^{a}$ Concentrations are in units of $10^{13}$ for $\mathrm{HONO}, 10^{11}$ for $\mathrm{OH}$, and $10^{15}$ for $\mathrm{CH}_{3} \mathrm{CD}_{2} \mathrm{CD}_{2} \mathrm{Br}$ all in molecule $\mathrm{cm}^{-3}, k_{4}$ is in units of $10^{-13}$ $\mathrm{cm}^{3}$ molecule ${ }^{-1} \mathrm{~s}^{-1}$, and the uncertainty given for $k_{4}$ is $2 \sigma$ precision from the fit to the data and does not include systematic uncertainties.

tures and there is a slight curvature in the Arrhenius plot); the $k_{2}(\mathrm{~T})-k_{5}(\mathrm{~T})$ values were also fit to the form $k_{i}(\mathrm{~T})=A T^{2} \exp [-$ $B / T]$. Table 7 summarizes the fit parameters. A qualitative trend in the site specific reaction rate coefficients or branching ratios ( $k_{1 \mathrm{a}} / k_{1}, k_{1 \mathrm{~b}} / k_{1}$, and $k_{1 \mathrm{c}} / k_{1}$ ) can be obtained from the measured values of $k_{1}-k_{5}$. For example, substituting ${ }^{\gamma} \mathrm{CD}_{3}$ for ${ }^{\gamma} \mathrm{CH}_{3}$ results in a small, $\sim 10 \%$, decrease in the measured rate coefficient over the entire temperature range, implying that the reaction at this position is small relative to the overall reaction. The rate coefficient for $\mathrm{CD}_{3} \mathrm{CH}_{2} \mathrm{CD}_{2} \mathrm{Br}$ is $\sim 70 \%$ of that for $\mathrm{CH}_{3} \mathrm{CH}_{2^{-}}$ $\mathrm{CH}_{2} \mathrm{Br}$, implying that significant abstraction occurs from the $\beta$ position. The rate coefficients for $\mathrm{OH}$ reaction with $\mathrm{CH}_{3} \mathrm{CD}_{2}$ $\mathrm{CD}_{2} \mathrm{Br}$ and $\mathrm{CD}_{3} \mathrm{CD}_{2} \mathrm{CD}_{2} \mathrm{Br}$ are $\sim 37 \%$ and $\sim 30 \%$, respectively, of the $\mathrm{OH}$ reaction with $\mathrm{CH}_{3} \mathrm{CH}_{2} \mathrm{CH}_{2} \mathrm{Br}$, indicating that the 
TABLE 6: Experimental Parameters Used for the Measurements of $k_{5}(\mathrm{~T})^{a}$

\begin{tabular}{ccccc}
\hline$K$ & {$[\mathrm{HONO}]$} & {$[\mathrm{OH}]_{0}$} & {$\left[\mathrm{CD}_{3} \mathrm{CD}_{2} \mathrm{CD}_{2} \mathrm{Br}\right]$} & $k_{5}$ \\
\hline 233 & 3.0 & 1.8 & $2.84-22.7$ & $1.83 \pm 0.04$ \\
242 & 6.1 & 3.3 & $3.28-26.5$ & $1.77 \pm 0.11$ \\
261 & 4.1 & 2.5 & $2.11-16.4$ & $2.18 \pm 0.08$ \\
282 & 3.1 & 1.7 & $3.50-14.7$ & $2.34 \pm 0.06$ \\
296 & 2.9 & 1.8 & $2.46-16.7$ & $3.30 \pm 0.16$ \\
300 & 3.4 & 2.0 & $2.50-14.9$ & $2.72 \pm 0.20$ \\
300 & 9.2 & 5.0 & $1.48-11.3$ & $2.89 \pm 0.07$ \\
315 & 5.5 & 2.9 & $1.77-14.6$ & $3.27 \pm 0.11$ \\
330 & 3.6 & 1.9 & $1.21-11.8$ & $3.80 \pm 0.21$ \\
345 & 5.9 & 3.2 & $1.18-11.6$ & $4.14 \pm 0.13$ \\
360 & 5.0 & 2.7 & $1.23-9.73$ & $4.64 \pm 0.08$
\end{tabular}

${ }^{a}$ Concentrations are in units of $10^{13}$ for HONO, $10^{11}$ for $\mathrm{OH}$, and $10^{15}$ for $\mathrm{CD}_{3} \mathrm{CD}_{2} \mathrm{CD}_{2} \mathrm{Br}$ all in molecule $\mathrm{cm}^{-3}, k_{5}$ is in units of $10^{-13}$ $\mathrm{cm}^{3}$ molecule ${ }^{-1} \mathrm{~s}^{-1}$, and the uncertainty given for $k_{4}$ is $2 \sigma$ precision from the fit to the data and does not include systematic uncertainties.

TABLE 7: Nonlinear Fit Parameters for $k_{1}(\mathrm{~T})$ through $k_{5}$ (T) in the Form $A T^{2} \exp (-B / R T)^{a}$

\begin{tabular}{ccr}
\hline compound & $A$ & \multicolumn{1}{c}{$B / \mathrm{R}$} \\
\hline $\mathrm{CH}_{3} \mathrm{CH}_{2} \mathrm{CH}_{2} \mathrm{Br}$ & $6.60 \pm 0.52$ & $-154 \pm 24$ \\
$\mathrm{CD}_{3} \mathrm{CH}_{2} \mathrm{CH}_{2} \mathrm{Br}$ & $6.04 \pm 0.79$ & $-147 \pm 40$ \\
$\mathrm{CD}_{3} \mathrm{CH}_{2} \mathrm{CD}_{2} \mathrm{Br}$ & $4.35 \pm 0.64$ & $-169 \pm 44$ \\
$\mathrm{CH}_{3} \mathrm{CD}_{2} \mathrm{CD}_{2} \mathrm{Br}$ & $8.76 \pm 1.37$ & $233 \pm 48$ \\
$\mathrm{CD}_{3} \mathrm{CD}_{2} \mathrm{CD}_{2} \mathrm{Br}$ & $4.67 \pm 0.77$ & $101 \pm 52$
\end{tabular}

${ }^{a} A$ is in units of $10^{-18} \mathrm{~cm}^{3}$ molecule ${ }^{-1} \mathrm{~s}^{-1}$, and the uncertainty given is $2 \sigma$ precision from the fit to the data and does not include systematic uncertainties.

majority of $\mathrm{H}$ atom abstraction occurs at the $\alpha$ and $\beta$ positions.

Product Branching Ratios. We have explored several methods of quantifying the branching ratios using the measured rate coefficient data, all of which yielded similar results. Here, we present the quantification obtained by assuming that (1) the reactivity of a given methyl or methylene group can be suppressed by deuterium substitution without altering the reactivity of the neighboring carbon sites and (2) that the impact of deuteration can be quantified. Tully and co-workers ${ }^{11,21,22}$ made the first assumption in their studies of deuterated propanes to determine the reactivity of individual methylene and methyl groups for both hydrogen and deuterium as a function of temperature. The ab initio calculations of $\mathrm{Hu}$ et al. ${ }^{23}$ confirmed, to a first approximation, the reactivity of an individual abstraction site was independent of neighboring alkyl groups. They also noted that tunneling was responsible for the difference in the kinetic isotope effects between the methyl and methylene groups.

Using the above assumptions at a given temperature, the rate coefficients, $k_{1}-k_{5}$, can then be written as a sum of site-specific rate coefficients. Assuming that the kinetic isotope effect is also independent of the site dependent rate coefficients (this assumption is discussed below)

$$
z=\frac{k_{1 \mathrm{c}}\left(\mathrm{CH}_{3}\right)}{k_{1 \mathrm{c}}\left(\mathrm{CD}_{3}\right)}=\frac{k_{1 \mathrm{~b}}\left(\mathrm{CH}_{2}\right)}{k_{1 \mathrm{~b}}\left(\mathrm{CD}_{2}\right)}=\frac{k_{1 \mathrm{a}}\left(\mathrm{CH}_{2} \mathrm{Br}\right)}{k_{1 \mathrm{a}}\left(\mathrm{CD}_{2} \mathrm{Br}\right)}
$$

we can write

$$
\begin{aligned}
& k_{1}=k_{1 \mathrm{c}}\left(\mathrm{CH}_{3}\right)+k_{1 \mathrm{~b}}\left(\mathrm{CH}_{2}\right)+k_{1 \mathrm{a}}\left(\mathrm{CH}_{2} \mathrm{Br}\right) \\
& k_{2}=\frac{k_{1 \mathrm{c}}\left(\mathrm{CH}_{3}\right)}{z}+k_{1 \mathrm{~b}}\left(\mathrm{CH}_{2}\right)+k_{1 \mathrm{a}}\left(\mathrm{CH}_{2} \mathrm{Br}\right)
\end{aligned}
$$

$$
\begin{aligned}
& k_{3}=\frac{k_{1 \mathrm{c}}\left(\mathrm{CH}_{3}\right)}{z}+k_{1 \mathrm{~b}}\left(\mathrm{CH}_{2}\right)+\frac{k_{1 \mathrm{a}}\left(\mathrm{CH}_{2} \mathrm{Br}\right)}{z} \\
& k_{4}=k_{1 \mathrm{c}}\left(\mathrm{CH}_{3}\right)+\frac{k_{1 \mathrm{~b}}\left(\mathrm{CH}_{2}\right)}{z}+\frac{k_{1 \mathrm{a}}\left(\mathrm{CH}_{2} \mathrm{Br}\right)}{z} \\
& k_{5}=\frac{k_{1 \mathrm{c}}\left(\mathrm{CH}_{3}\right)}{z}+\frac{k_{1 \mathrm{~b}}\left(\mathrm{CH}_{2}\right)}{z}+\frac{k_{1 \mathrm{a}}\left(\mathrm{CH}_{2} \mathrm{Br}\right)}{z}
\end{aligned}
$$

where $k_{1 \mathrm{c}}\left(\mathrm{CH}_{3}\right), k_{1 \mathrm{~b}}\left(\mathrm{CH}_{2}\right)$, and $k_{1 \mathrm{a}}\left(\mathrm{CH}_{2} \mathrm{Br}\right)$ are the site dependent rate coefficients at a given temperature and $k_{1 \mathrm{c}}\left(\mathrm{CD}_{3}\right), k_{1 \mathrm{~b}}\left(\mathrm{CD}_{2}\right)$, and $k_{1 \mathrm{a}}\left(\mathrm{CD}_{2} \mathrm{Br}\right)$ are the corresponding rate coefficients when hydrogen is replaced by deuterium. $z(\mathrm{~T})$ is then derived from a plot of $k_{1}(\mathrm{~T}) / k_{5}(\mathrm{~T})$ versus $1 / T$. Such a plot was slightly curved and yielded a fit of $z(\mathrm{~T})=1.429 \exp (254 / T)$.

Using $z$ for a given temperature and placing the equations for $k_{1}, k_{2}$, and $k_{3}$ in a matrix form yields

$$
\left|\begin{array}{lll}
1 & 1 & 1 \\
z^{-1} & 1 & 1 \\
z^{-1} & 1 & z^{-1}
\end{array}\right| \times\left|\begin{array}{l}
k_{1 \mathrm{c}}\left(\mathrm{CH}_{3}\right) \\
k_{1 \mathrm{~b}}\left(\mathrm{CH}_{2}\right) \\
k_{1 \mathrm{a}}\left(\mathrm{CH}_{2} \mathrm{Br}\right)
\end{array}\right|=\left|\begin{array}{l}
k_{1} \\
k_{2} \\
k_{3}
\end{array}\right|
$$

Using the measured rate coefficient data yields four combinations $\left\{\left(k_{1}, k_{2}, k_{3}\right),\left(k_{1}, k_{4}, k_{3}\right),\left(k_{5}, k_{2}, k_{3}\right),\left(k_{5}, k_{4}, k_{3}\right)\right\}$ which can be used to calculate site-specific rate coefficients. Thus, four values of $k_{1 \mathrm{c}}\left(\mathrm{CH}_{3}\right), k_{1 \mathrm{~b}}\left(\mathrm{CH}_{2}\right)$, and $k_{1 \mathrm{a}}\left(\mathrm{CH}_{2} \mathrm{Br}\right)$ and their deuterated analogues $\left(z^{-1} k_{1 \mathrm{c}}\left(\mathrm{CH}_{3}\right), z^{-1} k_{1 \mathrm{~b}}\left(\mathrm{CH}_{2}\right)\right.$, and $\left.z^{-1} k_{1 \mathrm{a}}\left(\mathrm{CH}_{2} \mathrm{Br}\right)\right)$ are obtained. Such calculations were done at each temperature to obtain $k_{1 \mathrm{c}}\left(\mathrm{CH}_{3}\right), k_{1 \mathrm{~b}}\left(\mathrm{CH}_{2}\right)$, and $k_{1 \mathrm{a}}\left(\mathrm{CH}_{2} \mathrm{Br}\right)$ as a function of temperature. The average of these was used to calculate total rate coefficients for the bromopropane isotopomers. These fits are shown in Figure 2 as dashed lines and the resulting temperature-dependent rate coefficients for each site are given in Table 8 . The site specific rate coefficients reproduce the measured values $k_{1}(\mathrm{~T})-k_{5}(\mathrm{~T})$, with the exception of the lowtemperature values of $k_{4}$, where the fit was $\sim 20 \%$ higher than the value calculated using Table 7 .

The kinetic isotope effect, $z(\mathrm{~T})$, used here is essentially an average of the kinetic isotope effects from the $\alpha$ and $\beta$ sites because these account for the majority of the reactivity (93$84 \%$ depending upon temperature). Assuming a different kinetic isotope for the methyl group could further refine our analysis. However, given the uncertainties in the measured values of $k_{1}$ $(\mathrm{T})-k_{5}(\mathrm{~T})$ and insensitivity to the $\gamma$ site rate coefficient (discussed below), such a refinement is inappropriate. We also note that the precision of these rate coefficients are $\sim 5 \%$ and would need to be even more precise to improve the branching ratios.

The site dependent rate coefficients were used to calculate the branching ratios for $\mathrm{H}$ (or D) abstraction at each carbon site. The branching ratios given in Table 9 are obtained from the site dependent rate coefficients (given in Table 8), and the presented uncertainty is one standard deviation of the average value obtained using the four sets of linear equations described above. The branching ratio for abstraction at the $\gamma$ site is small and, as seen in Table 9, has the largest relative uncertainty. Even a large $(20 \%)$ change in this rate coefficient, or changing the value of $z$ for this site, has little effect on the overall branching ratios. The methyl group branching ratio increases a factor of 2 from 230 to $360 \mathrm{~K}$, and the methylene group branching ratio decreases about $15 \%$ over this temperature range, whereas the $\mathrm{CH}_{2} \mathrm{Br}$ branching ratio is nearly temperature independent. These branching ratios are qualitatively consistent with the calculated 
TABLE 8: Site and Temperature Dependent Rate Coefficients Obtained by Fitting the Isotopic Data for Bromopropane

\begin{tabular}{ll}
\hline & $k(T) \mathrm{cm}^{3}$ molecule $^{-1} \mathrm{~s}^{-1}$ \\
\hline$k_{\mathrm{cc}}\left(\mathrm{CH}_{3}\right)$ & $2.89 \times 10^{-12} \exp (-957 / T)$ \\
$k_{\mathrm{bb}}\left(\mathrm{CH}_{2}\right)$ & $2.54 \times 10^{-18} T^{2} \exp (265 / T)^{a}$ \\
$k_{1 \mathrm{a}}\left(\mathrm{CH}_{2} \mathrm{Br}\right)$ & $1.44 \times 10^{-12} \exp (-450 / T)$ \\
$k_{1 \mathrm{c}}\left(\mathrm{CD}_{3}\right)$ & $1.45 \times 10^{-12} \exp (-1091 / T)$ \\
$k_{1 \mathrm{~b}}\left(\mathrm{CD}_{2}\right)$ & $1.11 \times 10^{-12} \exp (-560 / T)$ \\
$k_{1 \mathrm{a}}\left(\mathrm{CD}_{2} \mathrm{Br}\right)$ & $1.01 \times 10^{-12} \exp (-705 / T)$
\end{tabular}

${ }^{a}$ This nonlinear fit reproduces the data better than the Arrhenius form of $(2.48) \times 10^{-12} \exp (-437 / T) \mathrm{cm}^{3}$ molecule $\mathrm{s}^{-1} \mathrm{~s}^{-1}$.

TABLE 9: Average Branching Ratio Obtained from the Analyses Described in the Text (the Uncertainty Given Is 1 Standard Deviation)

\begin{tabular}{cccc}
\hline$K$ & $k_{1 \mathrm{c}} / k_{1}$ & $k_{1 \mathrm{~b}} / k_{1}$ & $k_{1 \mathrm{a}} / k_{1}$ \\
\hline 230 & $0.08 \pm 0.08$ & $0.61 \pm 0.02$ & $0.30 \pm 0.08$ \\
240 & $0.09 \pm 0.07$ & $0.60 \pm 0.02$ & $0.31 \pm 0.07$ \\
250 & $0.09 \pm 0.07$ & $0.60 \pm 0.02$ & $0.31 \pm 0.07$ \\
260 & $0.10 \pm 0.06$ & $0.59 \pm 0.02$ & $0.31 \pm 0.06$ \\
270 & $0.11 \pm 0.06$ & $0.58 \pm 0.02$ & $0.31 \pm 0.06$ \\
280 & $0.11 \pm 0.05$ & $0.57 \pm 0.02$ & $0.32 \pm 0.05$ \\
290 & $0.12 \pm 0.04$ & $0.56 \pm 0.02$ & $0.32 \pm 0.04$ \\
300 & $0.12 \pm 0.04$ & $0.56 \pm 0.02$ & $0.32 \pm 0.04$ \\
310 & $0.13 \pm 0.03$ & $0.55 \pm 0.02$ & $0.32 \pm 0.03$ \\
320 & $0.14 \pm 0.03$ & $0.54 \pm 0.02$ & $0.32 \pm 0.03$ \\
330 & $0.14 \pm 0.02$ & $0.54 \pm 0.02$ & $0.32 \pm 0.02$ \\
340 & $0.15 \pm 0.02$ & $0.53 \pm 0.02$ & $0.32 \pm 0.02$ \\
350 & $0.16 \pm 0.02$ & $0.52 \pm 0.02$ & $0.32 \pm 0.02$ \\
360 & $0.16 \pm 0.02$ & $0.52 \pm 0.02$ & $0.32 \pm 0.02$
\end{tabular}

${ }^{a}$ Because of round off, the sum may not equal 1.0.

TABLE 10: Branching Ratios at $298 \mathrm{~K}$ Determined in This Work and Those Used in Previous Modeling Studies ${ }^{a}$

\begin{tabular}{llll}
\hline \multicolumn{1}{c}{$k_{1 \mathrm{c}} / k_{1}$} & \multicolumn{1}{c}{$k_{\mathrm{lb}} / k_{1}$} & \multicolumn{1}{c}{$k_{\mathrm{la}} / k_{1}$} & \multicolumn{1}{c}{ method } \\
\hline $0.12 \pm 0.04$ & $0.56 \pm 0.02$ & $0.32 \pm 0.04$ & this work; OH kinetics \\
$<0.2$ & $0.5 \pm 0.2$ & $0.3 \pm 0.15$ & this work; product yields \\
0.18 & 0.47 & 0.35 & structure-reactivity ${ }^{37}$
\end{tabular}

bond energies (see below) that show the $\mathrm{C}-\mathrm{H}$ bond strength decreases in the order $\mathrm{CH}_{3}>\mathrm{CH}_{2} \mathrm{Br}>\mathrm{CH}_{2}$.

Previously, because of the absence of experimental data, the empirical structure-reactivity relationships of Atkinson ${ }^{9,10}$ was used to estimate product branching ratios for reaction $1 .^{7,8}$ The results of the structure-reactivity method at $298 \mathrm{~K}$ are given in Table 10, along with those from this study. Given that rate coefficients from the structure-reactivity relationships are expected to be within a factor of $\sim 2$ for the reaction of $\mathrm{OH}$ with alkanes, the agreement between the structure-reactivity estimate and the measured values is exceptional. The branching ratios obtained in this work are expected to be more precise; however, the trends are in qualitative agreement with those predicted using the structure-reactivity method.

Product Yields. Propanal and bromoacetone were observed as stable degradation products in both the $\mathrm{OH}$ and $\mathrm{Cl}$ atom initiated degradation of bromopropane in synthetic air containing NO. The bromopropanaldehyde, $\mathrm{BrCH}_{2} \mathrm{CH}_{2} \mathrm{C}(\mathrm{O}) \mathrm{H}$ was not identified in either the $\mathrm{OH}$ or $\mathrm{Cl}$ atom initiated experiments. $\mathrm{Cl}$ atom initiated bromopropane degradation experiments were performed for comparison purposes. The product yields of propanal and bromoacetone were quantified relative to each other (by using the $\mathrm{C}=\mathrm{O}$ stretch features near $1740 \mathrm{~cm}^{-1}$ ) and relative to the consumption of bromopropane. The measured infrared absorption cross sections of bromopropane were in excellent agreement with those previously published by Nelson et al. ${ }^{5}$ Propanal and bromoacetone absorption bands in spectral regions other than $1740 \mathrm{~cm}^{-1}$ were strongly overlapped and were not used in the data analysis.

Several experiments were performed to evaluate the detection sensitivity and stability of bromoacetone in the reaction cell. The infrared spectrum of bromoacetone was quantified using absolute pressure measurements. Bromoacetone was produced in the reactor by the reaction of $\mathrm{Br}$ atoms with propene in the presence of $\mathrm{NO}$ and $\mathrm{O}_{2}$

$$
\begin{aligned}
\mathrm{Br}+\mathrm{CH}_{3} \mathrm{CH}=\mathrm{CH}_{2} & \rightarrow \mathrm{CH}_{3} \mathrm{CHBrCH}_{2} \\
& \rightarrow \mathrm{CH}_{3} \mathrm{CHCH}_{2} \mathrm{Br}
\end{aligned}
$$

followed by the reactions

$$
\begin{gathered}
\mathrm{CH}_{3} \mathrm{CHCH}_{2} \mathrm{Br}+\mathrm{O}_{2} \rightarrow \mathrm{CH}_{3} \mathrm{CH}(\mathrm{OO}) \mathrm{CH}_{2} \mathrm{Br} \\
\mathrm{CH}_{3} \mathrm{CH}(\mathrm{OO}) \mathrm{CH}_{2} \mathrm{Br}+\mathrm{NO} \rightarrow \mathrm{CH}_{3} \mathrm{CH}(\mathrm{O}) \mathrm{CH}_{2} \mathrm{Br}+\mathrm{NO}_{2}
\end{gathered}
$$

$$
\mathrm{CH}_{3} \mathrm{CH}(\mathrm{O}) \mathrm{CH}_{2} \mathrm{Br}+\mathrm{O}_{2} \rightarrow \mathrm{CH}_{3} \mathrm{C}(\mathrm{O}) \mathrm{CH}_{2} \mathrm{Br}+\mathrm{HO}_{2}
$$

The $\mathrm{OH}$ radicals produced from $\mathrm{HO}_{2}$ (from reaction of $\mathrm{HO}_{2}+$ NO) lead to additional loss of propene via

$$
\mathrm{OH}+\mathrm{CH}_{3} \mathrm{CH}=\mathrm{CH}_{2} \rightarrow \text { Products }
$$

From the measured loss of propene and formation of bromoacetone, we estimate the yield of reaction $11 \mathrm{~b}$ to be $>70 \%$. Similar experiments using $\mathrm{Cl}$ atoms, instead of $\mathrm{Br}$, gave a chloroacetone yield of $\sim 30 \%$ in good agreement with the previously reported yields. ${ }^{24}$ Using pure samples, the dark and photolytic loss of bromoacetone was measured to be negligible on the time scale of the product yield experiments. ${ }^{15}$

Prior to using propanal and bromoacetone as markers for sitespecific $\mathrm{H}$ atom abstraction, it was necessary to verify the possible influence of secondary products. The $\mathrm{CH}_{3} \mathrm{CHCH}_{2} \mathrm{Br}$ radical formed by the $\mathrm{OH}$ attack on the central carbon atom can either add to $\mathrm{O}_{2}$ or eliminate a $\mathrm{Br}$ atom to produce propene

$$
\begin{gathered}
\mathrm{CH}_{3} \mathrm{CHCH}_{2} \mathrm{Br}+\mathrm{O}_{2} \rightarrow \mathrm{CH}_{3} \mathrm{CH}(\mathrm{OO}) \mathrm{CH}_{2} \mathrm{Br} \\
\mathrm{CH}_{3} \mathrm{CHCH}_{2} \mathrm{Br} \rightarrow \mathrm{CH}_{3} \mathrm{CH}=\mathrm{CH}_{2}+\mathrm{Br}
\end{gathered}
$$

The competition between $\mathrm{O}_{2}$ addition and $\mathrm{Br}$ elimination has been studied for the reaction of $\mathrm{Cl}$ with $\mathrm{CH}_{3} \mathrm{CH}_{2} \mathrm{Br}$, and the ethene yield was $2 \%$ in 500 Torr of $\mathrm{O}_{2}$ at $228 \mathrm{~K},{ }^{25}$ with $70-$ $80 \%$ of the $\mathrm{H}$ atom abstraction occurring from the $\mathrm{CH}_{2} \mathrm{Br}$ site. We have measured the yield of propene, a marker for $\mathrm{Br}$ elimination, relative to the loss of the $\mathrm{CH}_{3} \mathrm{CHCH}_{2} \mathrm{Br}$ radical in air. The ratio of the rate coefficients for reactions 16 and 17 was obtained from the yield of propene as a function of $\left[\mathrm{O}_{2}\right]$. The following equation relates the measured yield of propene with the rate coefficients:

$$
\left(k_{16} / k_{17}\right)\left[\mathrm{O}_{2}\right]=(1-\phi) / \phi
$$

where $\phi$ is the propene yield defined as the measured propene production rate with a given amount of $\mathrm{O}_{2}$ relative to the production rate in the absence of $\mathrm{O}_{2}$. A plot of the measured values versus $\left[\mathrm{O}_{2}\right]$ is shown in Figure 3 and yields $k_{16} / k_{17}=(4$ $\pm 0.6) \times 10^{-18} \mathrm{~cm}^{3}$ molecule ${ }^{-1}$. Although these measurements are rather limited, we conclude that, under the experimental conditions used to measure the yields of products in reaction 1 , the loss of $\mathrm{CH}_{3} \mathrm{CHCH}_{2} \mathrm{Br}$ radical via $\mathrm{Br}$ elimination is less than $10 \%$. 


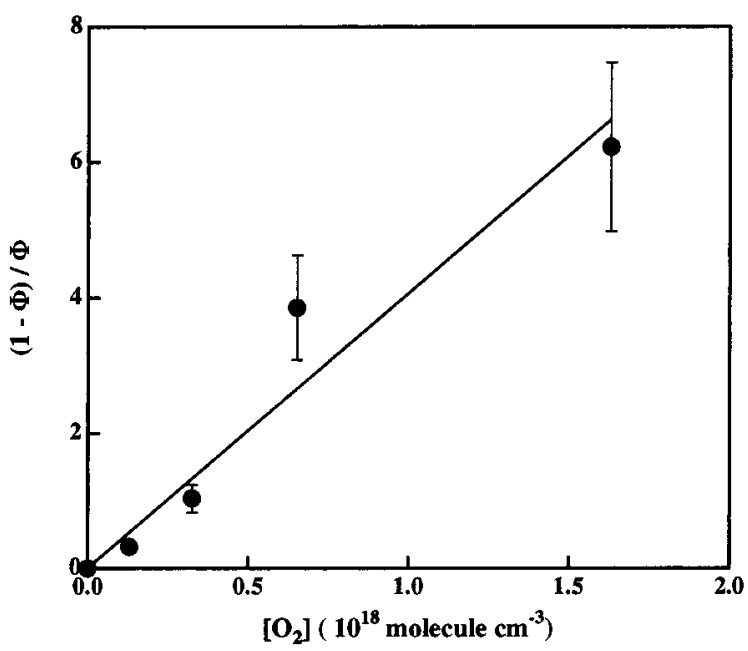

Figure 3. Determination of propene yield in the $\mathrm{Br}$ atom elimination from the $\mathrm{CH}_{3} \mathrm{CHCH}_{2} \mathrm{Br}$ radical using eq II given in the text.
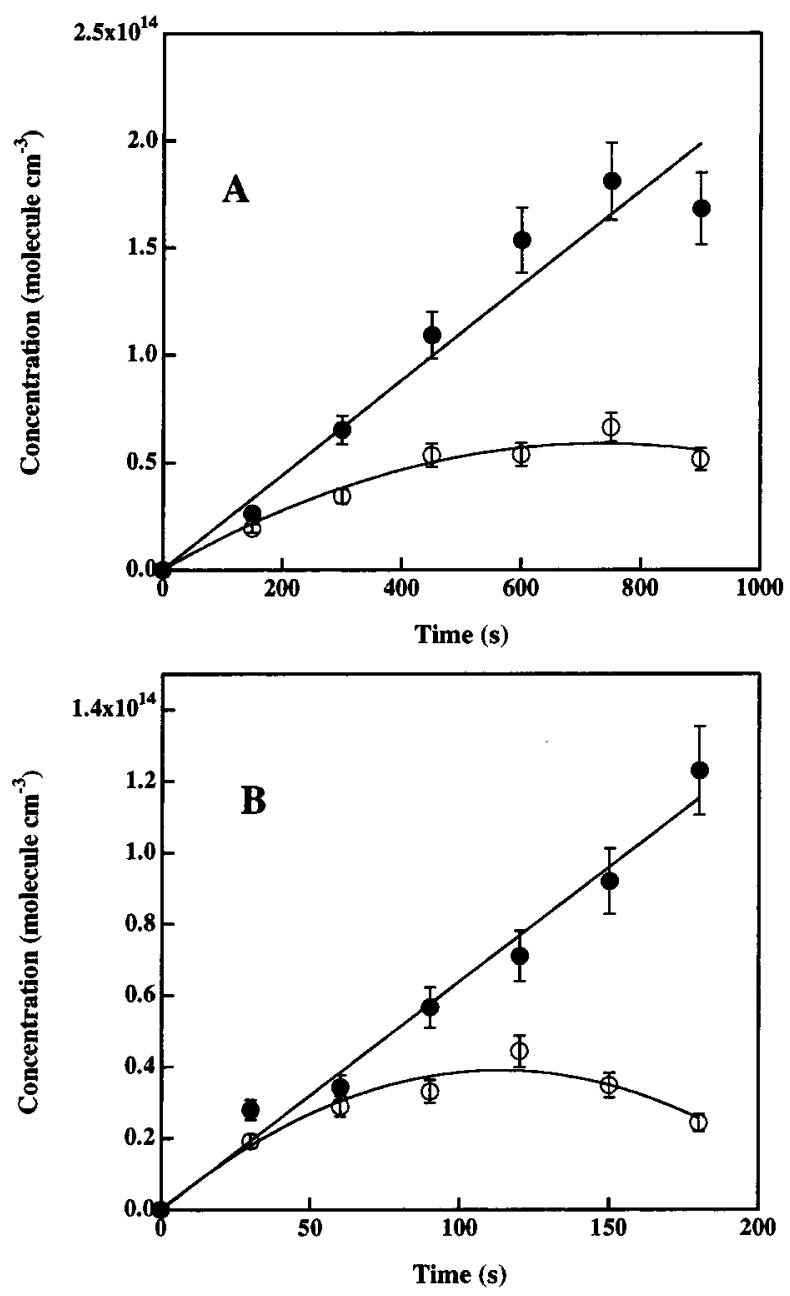

Figure 4. Product yield data for the (A) $\mathrm{OH}+$ bromopropane reaction and (B) $\mathrm{Cl}+$ bromopropane reaction. Solid symbols (-) are bromoacetone data and open symbols $(\mathrm{O})$ are propanal data.

The product yields of bromoacetone and propanal from reaction 1 were measured as described in the Experimental Section. The bromoacetone concentration increased monotonically during the course of an experiment, whereas the propanal signal increased initially and reached a plateau. Representative data for reaction with $\mathrm{OH}$ and $\mathrm{Cl}$ are shown in Figure 4 parts $\mathrm{A}$ and $\mathrm{B}$, respectively. The temporal profile of the propanal
TABLE 11: Computed Energies and Thermochemistry and Measured Reactivity of Specific Bonds in Propane and Bromopropane

\begin{tabular}{lcccc}
\hline \multicolumn{1}{c}{ species } & $\mathrm{G} 3(0 \mathrm{~K}) \mathrm{au}^{a}$ & $\begin{array}{c}\mathrm{H}_{298}-\mathrm{H}_{0}, \\
\mathrm{kcal} \mathrm{mol}^{-1}\end{array}$ & $\begin{array}{c}\mathrm{BDE}_{298}, \\
\mathrm{kcal} \mathrm{mol}^{-1}\end{array}$ & $\begin{array}{c}k \\
(298 \mathrm{~K})^{b}\end{array}$ \\
\hline $\mathrm{CH}_{3} \mathrm{CH}_{2} \mathrm{CH}_{3}$ & -118.99389 & 3.6 & & \\
$\mathrm{CH}_{3} \mathrm{CH}_{2} \mathrm{CH}_{2}$ & -118.33391 & 3.7 & 101.3 & 0.5 \\
$\mathrm{CH}_{3} \mathrm{CHCH}_{3}$ & -118.33814 & 3.8 & 98.7 & 4.0 \\
$\mathrm{CH}_{3} \mathrm{CH}_{2} \mathrm{CH}_{2} \mathrm{Br}$ & -2691.96438 & 4.2 & & \\
$\mathrm{CH}_{3} \mathrm{CH}_{2} \mathrm{CHBr}$ & -2691.30819 & 4.3 & 99.0 & 1.6 \\
$\mathrm{CH}_{3} \mathrm{CHCH}_{2} \mathrm{Br}$ & -2691.31278 & 4.4 & 96.1 & 2.7 \\
$\mathrm{CH}_{2} \mathrm{CH}_{2} \mathrm{CH}_{2} \mathrm{Br}$ & -2691.30417 & 4.3 & 101.5 & 0.4
\end{tabular}

${ }^{a}$ Gaussian-3 energy. 1 au $\sim 627.4 \mathrm{kcal} \mathrm{mol}{ }^{-1} \cdot{ }^{b}$ Rate coefficient per $\mathrm{C}-\mathrm{H}$ bond, in units of $10^{-13} \mathrm{~cm}^{3}$ molecule ${ }^{-1} \mathrm{~s}^{-1}$.

product indicates that significant secondary loss of this product is occurring during the course of these measurements. The secondary loss results from reaction with $\mathrm{OH}$ or $\mathrm{Cl}$ atoms and possibly other reaction intermediates. ${ }^{26}$ Therefore, our determination of the propanal yield is primarily determined by the initial data points and an empirical extrapolation to time zero. The reactivity of bromoacetone with $\mathrm{OH}$ and $\mathrm{Cl}$ is expected to be relatively slow by analogy with the acetone and chloroacetone reactions. ${ }^{27,28} \mathrm{Cl}$ atom relative rate reactions performed during the course of this work confirmed this expectation. Therefore, secondary reactive losses of bromoacetone are negligible. Using the slope of the initial growth of the propanal signal, we determined the ratio of the bromoacetone to propanal yield to be $1.65 \pm 0.50$ and $1.1 \pm 0.35$ in the $\mathrm{OH}$ and $\mathrm{Cl}$ atom reactions, respectively. The absolute yield of bromoacetone based on the loss of bromopropane was measured to be $50 \pm 20 \%$ in the $\mathrm{OH}$ reaction. We estimate the yield of $\mathrm{BrCH}_{2} \mathrm{CH}_{2} \mathrm{C}(\mathrm{O}) \mathrm{H}$ to be $<20 \%$. The uncertainty in the product yields is substantial because of the relatively small changes in the bromopropane concentrations, weak product absorption signals, and the spectral overlap of the product spectra. The quoted uncertainties are estimated based on the precision and reproducibility of the measurements.

Ab Initio Calculations. To obtain some insight into the experimentally derived site-specific reactivity, we carried out ab initio calculations using the Gaussian 98 program $^{29}$ to obtain bond strength and relative rate coefficients. The Gaussian-3 (G3) methodology of Pople and co-workers, ${ }^{30}$ as extended to bromine compounds by Curtiss et al., ${ }^{31}$ was employed to derive energies of reactants, transition states, and products. Briefly, for each species, the vibrational frequencies were obtained at the $\mathrm{HF} /$ 6-31G(d) level of theory (scaled by a standard factor of 0.8929 ), and then a series of single-point energies was calculated at the MP2=full/6-31G(d) geometries to approximate a QCISD$(\mathrm{T})=$ full/G3Large calculation, where the G3Large basis set for $\mathrm{Br}$ is a contracted $8 \mathrm{~s} 7 \mathrm{p} 3 \mathrm{~d}$ basis supplemented with diffuse, $3 \mathrm{~d} 2 \mathrm{f}$ polarization and tight $d, f$ polarization functions. The basis sets, including a redefined $6-31 \mathrm{G}(\mathrm{d})$ set for $\mathrm{Br}$, are detailed elsewhere. ${ }^{30-32}$ The $\mathrm{Br} 3 \mathrm{~d}$ orbitals were included in the correlation treatments, and a spin-orbit correction was made to the $\mathrm{OH}$ radical energy. ${ }^{30}$

The unknown bond strengths, $D_{0}$, at $298 \mathrm{~K}$ for the three $\mathrm{C}-\mathrm{H}$ bonds $(\alpha, \beta$, and $\gamma$ positions) in bromopropane were obtained via $\Delta H_{0}$ for the isodesmic reactions

$$
\mathrm{C}_{2} \mathrm{H}_{5}+\mathrm{CH}_{3} \mathrm{CH}_{2} \mathrm{CH}_{2} \mathrm{Br} \rightarrow \mathrm{C}_{2} \mathrm{H}_{6}+\mathrm{C}_{3} \mathrm{H}_{6} \mathrm{Br}
$$

obtained from the $\mathrm{G} 3$ energies, to which were added thermal corrections $\left(H_{298}-H_{0}\right.$ given in Table 11$)$ derived from the vibrational frequencies and including corrections for hindered internal rotors. ${ }^{33}$ The net thermal corrections for $\Delta H_{298}$ were 


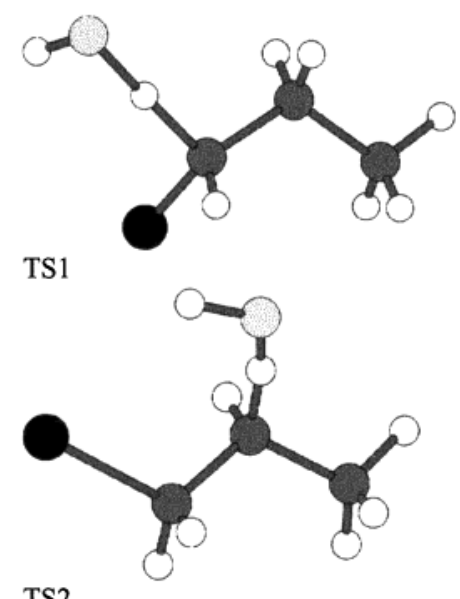

TS2

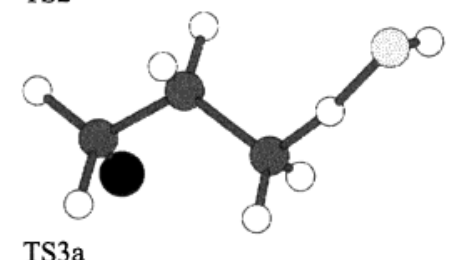

TS3a

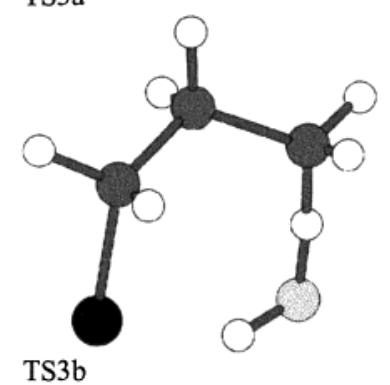

Figure 5. Transition state geometries calculated at the $\mathrm{HF} / 6-31 \mathrm{G}(\mathrm{d})$ level of theory for the $\mathrm{OH}+\mathrm{CH}_{3} \mathrm{CH}_{2} \mathrm{CH}_{2} \mathrm{Br}$ reaction.

small, because the number of bonds of each type is conserved in reaction 18. Similarly, errors arising from incomplete basis sets and electron correlation are also expected to cancel. The $D_{298}$ values are listed in Table 11 , together with the primary and secondary bond strengths in propane derived in the same way. The computed propane data are in excellent accord with experimental data: our primary $D_{298}=101.3 \mathrm{kcal} \mathrm{mol}^{-1}$ can be compared to literature values of 101.0 and $101.2 \pm 0.5 \mathrm{kcal}$ $\mathrm{mol}^{-1}, 34,35$ and our secondary $\mathrm{D}_{298}=98.7 \mathrm{kcal} \mathrm{mol}^{-1}$ lies in the middle of prior determinations of $99.3,97.8 \pm 0.5$, and 98.6 $\pm 0.4 \mathrm{kcal} \mathrm{mol}^{-1} \cdot 34-36$

Br substitution (relative to propane) weakens the $\mathrm{C}-\mathrm{H}$ bonds by $2.3 \mathrm{kcal} \mathrm{mol}^{-1}$ for the $\alpha$ position and $2.6 \mathrm{kcal} \mathrm{mol}^{-1}$ for the $\beta$ position and leaves the most distant $(\gamma)$ bond almost unaffected (increased by $0.2 \mathrm{kcal} \mathrm{mol}^{-1}$ ). Presumably, the halogen in bromopropane acts, perhaps unexpectedly, as an electron donor toward the electron deficient carbon in the $n$-bromopropyl and $i$-bromopropyl radicals. The bond strengths are in qualitative accord with the kinetics: as seen in Table 11, within propane and bromopropane, the weakest $\mathrm{C}-\mathrm{H}$ bonds have the highest per bond reactivity.

Transition states (TSs) for $\mathrm{OH}$ attack at the $(\alpha),(\beta)$, and $(\gamma)$ sites are shown in Figure 5, the detailed coordinates and vibrational frequencies are given in the Supporting Information Tables S2-S5, and the G3 energy barriers relative to reactants at $0 \mathrm{~K}, E_{0}$, are listed in Table 12. These structures, where possible, have the hydroxyl group oriented toward the $\mathrm{Br}$ atom suggestive of an attractive interaction that stabilizes $\alpha \mathrm{TS} 1, \beta \mathrm{TS} 2$, and $\gamma \mathrm{TS} 3 \mathrm{~b}$, and the $\mathrm{H}-\mathrm{Br}$ separations are $3.3 \times 10^{-10}$ (five-
TABLE 12: Properties of Transition States Based on ab Initio Calculations and Fits to Experiment

\begin{tabular}{ccc}
\hline \multicolumn{1}{c}{ transition state } & $\mathrm{G} 3(0 \mathrm{~K}), \mathrm{au}^{a}$ & $\begin{array}{c}\text { calculated } E_{0}, \\
\mathrm{kcal} \mathrm{mol}^{-1 \mathrm{~b}}\end{array}$ \\
\hline$\alpha$ TS1 OH $+\mathrm{CH}_{3} \mathrm{CH}_{2} \mathrm{CH}_{2} \mathrm{Br}$ & -2767.65806 & 1.0 \\
$\alpha$ TS1 OH $+\mathrm{CD}_{3} \mathrm{CD}_{2} \mathrm{CD}_{2} \mathrm{Br}$ & & 2.1 \\
$\beta$ TS2 $\mathrm{OH}+\mathrm{CH}_{3} \mathrm{CH}_{2} \mathrm{CH}_{2} \mathrm{Br}$ & -2767.65961 & 0.0 \\
$\beta$ TS2 OH $+\mathrm{CD}_{3} \mathrm{CD}_{2} \mathrm{CD}_{2} \mathrm{Br}$ & & 1.1 \\
$\gamma$ TS3a OH $+\mathrm{CH}_{3} \mathrm{CH}_{2} \mathrm{CH}_{2} \mathrm{Br}$ & -2767.65493 & 2.9 \\
$\gamma$ TS3a OH $+\mathrm{CD}_{3} \mathrm{CD}_{2} \mathrm{CD}_{2} \mathrm{Br}$ & & 4.0 \\
$\gamma$ TS3b OH $+\mathrm{CH}_{3} \mathrm{CH}_{2} \mathrm{CH}_{2} \mathrm{Br}$ & -2767.65569 & 2.4 \\
$\gamma$ TS3b OH $+\mathrm{CD}_{3} \mathrm{CD}_{2} \mathrm{CD}_{2} \mathrm{Br}$ & & 3.6
\end{tabular}

${ }^{a}$ Gaussian 3 energy. 1 au $\sim 627.4 \mathrm{kcal} \mathrm{mol}^{-1} \cdot{ }^{b}$ Calculated barrier based on G3 energies, corrected for zero-point energy changes in the deuterium reactions.

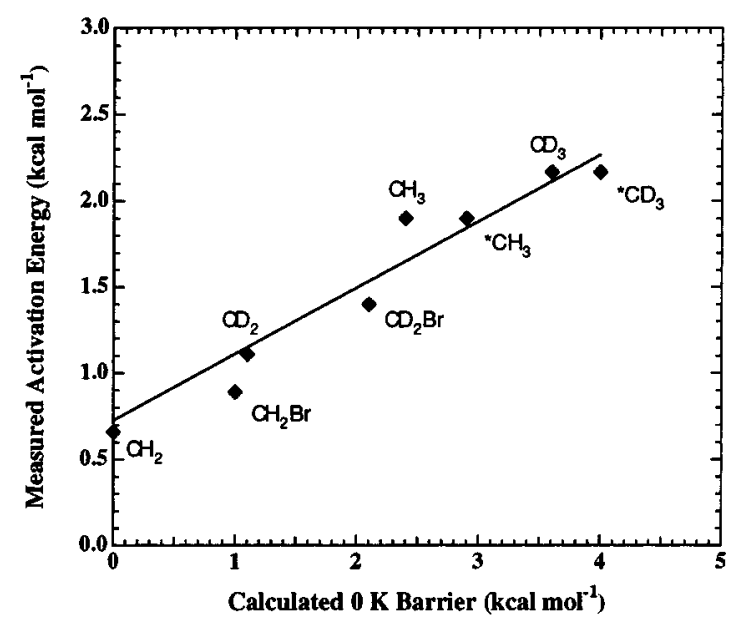

Figure 6. Calculated transition state theory barrier for $\mathrm{H}$ abstraction from each carbon site versus $298 \mathrm{~K}$ activation energy for the site dependent rate coefficients given in Table 8 . These are taken from the Arrhenius fits, except for the $\mathrm{CH}_{2}$ nonlinear fit for which $E_{\mathrm{a}} / R=2 T-$ 265 . These are labeled $\mathrm{CH}_{2} \mathrm{Br}\left(\mathrm{CD}_{2} \mathrm{Br}\right)$ for $\alpha \mathrm{TS} 1, \mathrm{CH}_{2}\left(\mathrm{CD}_{2}\right)$ for $\beta \mathrm{TS} 2$, ${ }^{*} \mathrm{CH}_{3}\left({ }^{*} \mathrm{CD}_{3}\right)$ for $\gamma \mathrm{TS} 3 \mathrm{a}$, and $\mathrm{CH}_{3}\left(\mathrm{CD}_{3}\right)$ for $\gamma \mathrm{TS} 3 \mathrm{~b}$.

membered ring), $2.9 \times 10^{-10}$ (six-membered ring), and $2.1 \times$ $10^{-10} \mathrm{~m}$ (seven-membered ring). Two distinct transition states were found for attack at the $\gamma \mathrm{C}-\mathrm{H}$ bonds. The lower energy $\gamma \mathrm{TS} 3 \mathrm{~b}$ has $\mathrm{OH}$ approaching a $\mathrm{C}-\mathrm{H}$ bond close to in-plane with the $\mathrm{C}-\mathrm{C}-\mathrm{C}-\mathrm{Br}$ backbone, which allows for formation of the seven-membered ring. $\gamma \mathrm{TS} 3 \mathrm{a}$, where $\mathrm{H}-\mathrm{Br}$ stabilization cannot occur, is $0.5 \mathrm{kcal} \mathrm{mol}^{-1}$ higher in energy but also looser.

Figure 6 shows a clear correlation between the computed 0 $\mathrm{K}$ barriers, $E_{0}$, and the measured site and isotope specific activation energies, $E_{\mathrm{a}}$, at $298 \mathrm{~K}$. A more quantitative comparison would require accurate estimation of the influence of quantum mechanical tunneling which is beyond the scope of the present work. Nevertheless it may be seen that the trend in observed $E_{\mathrm{a}}$ is consistent with that expected on the basis of ab initio analysis.

\section{Conclusions}

We have measured temperature dependent rate coefficients for selectively deuterated bromopropanes. These rate coefficients were used to obtain product branching ratios for $\mathrm{H}$ (or D) atom abstraction on each carbon site. The change in rate coefficients for the various isotopomers at $298 \mathrm{~K}$ yielded rough estimates of the branching ratios. Fitting site dependent rate coefficients to our data yielded $298 \mathrm{~K}$ values of $k_{1 \mathrm{c}} / k_{1}=0.12, k_{1 \mathrm{~b}} / k_{1}=$ 0.56 , and $k_{1 \mathrm{a}} / k_{1}=0.32$. These product branching ratios are consistent with the product measurement yields of bromoacetone $(0.5 \pm 0.2)$ and the ratio of bromoacetone/propanal (1.65 \pm 
0.50) obtained in synthetic air. They are also consistent with the ab initio calculations for $\mathrm{C}-\mathrm{H}$ bond energies in bromopropane relative to those in propane. The branching ratios obtained from measurements of the rate coefficients are also consistent with the trends in the ab initio calculations. These branching ratios can be used for atmospheric calculations.

Acknowledgment. We wish to acknowledge funding from NOAA's Global and Climate Change Program and NASA Upper Atmospheric Research Program. J.B.B. thanks J. J. Orlando for helpful discussions. M.K.G. thanks V. Orkin for providing experimental results on the $\mathrm{OH}+\mathrm{CH}_{3} \mathrm{CH}_{2} \mathrm{CH}_{2} \mathrm{Br}$ prior to publication, A. Mellouki for providing unpublished data on the $\mathrm{OH}+\mathrm{CH}_{3} \mathrm{C}(\mathrm{O}) \mathrm{CH}_{2} \mathrm{Cl}$ reaction, and $\mathrm{R}$. Atkinson for helpful comments on the structure-reactivity method calculations. P.M. thanks the Robert A. Welch Foundation (Grant B-1174) and the National Center for Supercomputing Applications (Grant CHE000015N).

Supporting Information Available: Details of the gas chromatography/mass spectrometry analyses for each compound and an estimate of their contribution to the measured reaction rate coefficients at $230 \mathrm{~K}$ are given in Tables S1a-S1e. Transition states (TSs) for $\mathrm{OH}$ attack at the $(\alpha),(\beta)$, and $(\gamma)$ sites are shown in Figure 5, and the detailed coordinates and vibrational frequencies are given in Tables S2-S5. This material is available free of charge via the Internet at http://pubs.acs.org.

\section{References and Notes}

(1) Téton, S.; Boudali, A. E.; Mellouki, A. J. Chim. Phys. 1996, 93, 274.

(2) Herndon, S. C.; Gierczak, T.; Talukdar, R. K.; Ravishankara, A. R. Phys. Chem. Chem. Phys. 2001, 3, 4529.

(3) Orkin, V. L.; Kozlov, S. N.; Louis, F. J.; Huie, R. E.; Kurylo, M. J. Atmospheric Fate of Some Short-Lived Br Containing Hydrohalocarbons: OH Reactions and UV Spectra; Workshop on Laboratory Studies of Upper Troposphere/Lower Stratosphere Processes, Breckenridge, CO, 2001.

(4) Donaghy, T.; Shanahan, I.; Hande, M.; Fitzpatrick, S. Int. J. Chem. Kinet. 1993, 25, 273.

(5) Nelson, J. D. D.; Wormhoudt, J. C.; Zahniser, M. S.; Kolb, C. E.; Ko, M. K. W.; Weisenstein, D. K. J. Chem. Phys. A 1997, 101, 4987.

(6) Wuebbles, D. J.; Jain, A. K.; Patten, K. O. Atmos. Environ. 1998, $32,107$.

(7) Bridgeman, C. H.; Pyle, J. A.; Shallcross, D. E. J. Geophys. Res. Atmos. 2000, 105, 26493.

(8) Wuebbles, D. J.; Patten, K. O.; Johnson, M. T.; Kotamarthi, R. J. Geo. Res. 2001, 106, 14

(9) Atkinson, R. Int. J. Chem. Kinet. 1987, 19, 799.

(10) Kwok, E. S. C.; Atkinson, R. Atmos. Environ. 1995, 29, 1685.

(11) Droege, A. T.; Tully, F. P. J. Phys. Chem. 1986, 90, 1949. 1948 .

(12) Vaghjiani, G. L.; Ravishankara, A. R. J. Phys. Chem. 1989, 93,
(13) DeMore, W. B.; Sander, S. P.; Golden, D. M.; Hampson, R. F.; Kurylo, M. J.; Howard, C. J.; Ravishankara, A. R.; Kolb, C. E.; Molina, M. J. Chemical Kinetics and Photochemical Data for Use in Stratospheric Modeling; Jet Propulsion Laboratory: Pasadena, CA, 1997.

(14) Gas-Phase Tropospheric Chemistry of Organic Compounds; Atkinson, R., Ed.; American Institute of Physics: New York, 1994; Vol. Monogram 2.

(15) Burkholder, J. B.; Gilles, M. K.; Gierczak, T.; Ravishankara, A. R. Geophys. Res. Lett. 2002, in press.

(16) Burkholder, J. B.; Orlando, J. J.; Howard, C. J. J. Phys. Chem. 1990, 94, 687.

(17) Gierczak, T.; Burkholder, J. B.; Bauerle, S.; Ravishankara, A. R. Chem. Phys. 1998, 231, 229.

(18) Bedjanian, Y.; LeBras, G.; Poulet, G. Int. J. Chem. Kinet. 1999, 31,698 .

(19) Gilles, M. K.; Burkholder, J. B.; Ravishankara, A. R. Int. J. Chem. Kinet. 1999, 31, 417.

(20) Maric, D.; Burrows, J. P.; Moortgat, G. K. J. Photochem. Photobiol. A: Chem. 1994, 83, 179 .

(21) Droege, A. T.; Tully, F. P. J. Phys. Chem. 1986, 90, 5937.

(22) Tully, F. P.; Droege, A. T.; Koszykowski, M. L.; Melius, C. F. J. Phys. Chem. 1986, 90, 691.

(23) Hu, W. P.; Rossi, I.; Corchado, J. C.; Truhlar, D. G. J. Phys. Chem. A. 1997, 101, 6911.

(24) Kleindienst, T. E.; Shepson, P. B.; Nero, C. M.; Bufalini, J. J. Int J. Chem. Kinet. 1989, 21, 863 .

(25) Orlando, J. J.; Tyndall, G. S. J. Phys. Chem. A. 2002, 106, 312.

(26) Atkinson, R.; Baulch, D. L.; Cox, R. A.; Hampson, K. F., Jr.; Kerr, J. A.; Rossi, M. J.; Troe, J. J. Phys. Chem. Ref. Data 1997, 26, 521.

(27) Notario, A.; Mellouki, W.; Le Bras, G. Int. J. Chem. Kinet. 2000, 32,62 .

(28) Mellouki, W. 2002, to be published.

(29) Frisch, M. J.; Trucks, G. W.; Schlegel, H. B.; Scuseria, G. E.; Robb,

M. A.; Cheeseman, J. R.; Zakrzewski, V. G.; Montgomery, J. A., Jr.; Stratmann, R. E.; Burant, J. C.; Dapprich, S.; Millam, J. M.; Daniels, A. D.; Kudin, K. N.; Strain, M. C.; Farkas, O.; Tomasi, J.; Barone, V.; Cossi, M.; Cammi, R.; Mennucci, B.; Pomelli, C.; Adamo, C.; Clifford, S.; Ochterski, J.; Petersson, G. A.; Ayala, P. Y.; Cui, Q.; Morokuma, K.; Malick, D. K.; Rabuck, A. D.; Raghavachari, K.; Foresman, J. B.; Cioslowski, J.; Ortiz, J. V.; Stefanov, B. B.; Liu, G.; Liashenko, A.; Piskorz, P.; Komaromi, I.; Gomperts, R.; Martin, R. L.; Fox, D. J.; Keith, T.; Al-Laham, M. A.; Peng, C. Y.; Nanayakkara, A.; Gonzalez, C.; Challacombe, M.; Gill, P. M. W.; Johnson, B. G.; Chen, W.; Wong, M. W.; Andres, J. L.; Head-Gordon, M.; Replogle, E. S.; Pople, J. A. Gaussian 98; Gaussian, Inc.: Pittsburgh, PA, 1998.

(30) Curtiss, L. A.; Raghavachari, K.; Redfern, P. C.; Rassolov, V.; Pople, J. A. J. Chem. Phys. 1998, 109, 7764.

(31) Curtiss, L. A.; Redfern, P. C.; Rassolov, V.; Kedziora, G.; Pople, J. A. J. Chem. Phys. 2001, 114, 9998.

(32) Rassolov, V.; Ratner, M. A.; Pople, J. A.; Redfern, P. C.; Curtiss, L. A. J. Comput. Chem. 2001, 22, 976.

(33) Ayala, P. Y.; Schlegel, H. B. J. Chem. Phys. 1998, 108, 2314.

(34) Tsang, W. J. Am. Chem. Soc. 1985, 107, 2872.

(35) Seetula, J. A.; Slagel, I. R. J. Chem. Soc., Faraday Trans. 1997, 93,1709 .

(36) Seakins, P. W.; Pilling, M. J.; Niiranen, J. T.; Gutman, D.; Krasnoperov, L. M. J. Phys. Chem. 1992, 96, 9847.

(37) Atkinson, R. Handbook of Property Estimation Methods for Chemicals Environmental and Health Sciences; CRC Press LLC: Boca Raton, FL, 2000. 